\title{
Innovative Capacity, Educational Attainment and Economic Development in the European Union: Causal Relations and Geographical Variations
}

ARTICLE in EUROPEAN PLANNING STUDIES · DECEMBER 2013

Impact Factor: $1.03 \cdot$ DOI: 10.1080/09654313.2012.722968

CITATION

1

2 AUTHORS:

Teemu Makkonen

University of Surrey

21 PUBLICATIONS 17 CITATIONS

SEE PROFILE
Tommi Inkinen

University of Helsinki

35 PUBLICATIONS 67 CITATIONS

SEE PROFILE 


\title{
Innovative Capacity, Educational Attainment and Economic Development in the European Union: Causal Relations and Geographical Variations
}

\author{
TEEMU MAKKONEN \& TOMMI INKINEN
}

Department of Geosciences and Geography, University of Helsinki, Finland

\begin{abstract}
This paper sets out to examine the innovative capacity of the European Union countries and regions vis-à-vis educational attainment and economic development, as it is frequently stated that innovation and the availability of human capital, specifically education, are the key drivers of economic growth. In addition to the aggregate level, the countries and NUTS-2 regions of the European Union, and traditional indicators of the studied dimensions, were used as observation units. Granger causality test identified education as a driving force behind innovative capacity and economic development whereas the relationship between innovative capacity and economic development is bidirectional. The study results also confirm the existence of innovation paradoxes in form of rising research and development expenditures but modest rate of GDP growth. The implications of the results concern the recognition of spatial generalisations and national variations, identification and creation of development strategies and the horizontal and vertical collaborations between the public and private sectors.
\end{abstract}

This is an Accepted Manuscript of an article published by Taylor \& Francis Group in European Planning Studies on 13 Sep 2012, Vol. 21, No. 12, pp. 1958-1976. Available online: http://www.tandfonline.com/doi/abs/10.1080/09654313.2012.722968

\section{Introduction}

The European Union (EU) enlarged to include 27 countries in 2007. The new member states broadened the national and regional diversities within the Union, and this paper sets out to explore the causal relations between innovative capacity, educational attainment and economic condition in the enlarged EU. Gössling and Rutten (2007) state that a vital, if not the only, driver of economic growth is the link between innovations and economic development. This notion is bidirectional: innovation creates economic development and a certain stage of economic development is needed to produce innovations. However, the paper is motivated by Strulik's (2005) statement that while economic growth is explained through innovation, it is ultimately driven by (educated) human capital. At the same time the innovativeness of a particular region attracts educated human capital to that region (Fag

Corresponding Address: Teemu Makkonen, Department of Geosciences and Geography, University of Helsinki, PO Box 64, 00014, Finland. E-mail: teemu.makkonen@ helsinki.fi 
gian \& McCann, 2009). This paper aims to fill a gap in the literature through focussing on detailed analyses of the causal interconnections between innovative capacity, educational attainment and economic development (cf. Crescenzi \& Rodríguez-Pose, 2011). The paper conforms to the view that innovative capacity plays a key role in the process of economic growth, but it also recognises that the causal relationships between socio-economic factors are blurred and debatable.

The paper falls within the tradition of regional studies that, as recently discussed by Krugman (2011) and Storper (2011), deal with 'new economic geography': the analysis is based on a macrolevel analysis of the regional condition in the EU. This paper presents layered spatial approach to analyse the relationships between, at the EU level, and the geographical diversity of, at the national and regional scales, the innovative capacity, educational attainment and economic condition. The paper provides an analysis of specific questions concerning 1) the direction of causal relations between the studied dimensions and; 2) the extent of the geographical variations inside the EU in these dimensions. To address the presented questions, panel data on the studied dimensions on aggregate and different European regional scales are presented and analysed with Granger causality tests. The studied spatial scales are the Nomenclature of Territorial Units for Statistics (NUTS) 0 and 2. The emerging anomalies in the hypothesised best fit line between the dimensions are discussed to show how well economic development, educational attainment and innovative capacity work in tandem with one another. The combination of applying three spatial scales brings forth the problematic of fragmentation and loss of spatial information when applying larger geographical data sources. This approach contributes to existing literature through the use of changing spatial scale (EU, countries, NUTS2) and Granger causality (lags). The quantified results are interpreted in the light of policy implications.

The paper is organised as follows. First, a selection of relevant literature is reviewed. Second, a detailed consideration of data and methods and a discussion of their limitations are presented. Third, the results of the conducted analyses are demonstrated and explained. Fourth, the results are discussed in wider context. Finally, by way of conclusion the most relevant results and implications are recapped and highlighted and directions for further research are suggested.

\section{Debates Concerning Regional Innovation Systems, Clusters and Capacity in Literature}

Regions and nations function as the spatial contexts for human actions including innovation activities. A related field of discussion is that of innovation clusters, inspired largely by the works of Michael Porter (e.g. 1990; 1998; 2003), in which the main driver of heightened innovation tendency is the proximity of different innovative actors and the cooperation and competition between them (Moreno et al., 2005). Proximity allows trust to be built between actors through informal contact, i.e. face-toface communication and knowledge exchange, especially tacit knowledge, which results in the better 
innovation performance of individual regions (Maskell \& Malmberg, 1999; Molina-Morales \& MasVerdu, 2008). Geographical proximity, however, is not enough to account for the improved innovation capability as there are other types of proximity including organisational and social proximity (Boschma, 2005).

Another widely studied concept in terms of development policies has been innovation system(s). Innovation systems are primarily based on the cooperation and interconnection between public organisations, private sector and universities (Lundvall \& Maskell, 2000): the literature on innovation systems suggests that the differences in the institutions (laws, norms, policies, culture), innovation infrastructure (universities, research institutes, think tanks) and the structure of the economy should have an effect on the innovation performances of countries and regions (e.g. Balzat \& Hanusch, 2004; Doloreux \& Parto, 2005). Thus the overall innovation performance of a region is not only dependent on the innovation performance of firms, but also on the frequency of interactions, evolution of regional social capabilities and modes of governance (Iammarino, 2005). Businesses with greater involvement with local institutions and associations achieve better innovation performance (MolinaMorales \& Mas-Verdu, 2008). Accordingly, it seems that a certain amount of local research and development (R\&D) effort is a necessity for a region aspiring to the hypothesised economic growth (e.g. Rodríguez-Pose, 1999). The innovative capacities of regions are also influenced by growing interregional cooperation and globalisation (see Simmie et al., 2002).

As the literature on innovation systems and clusters suggests, innovation performance is unevenly distributed across the geographical landscape (Moodyson et al., 2008) and, thus, it is also unequally distributed across Europe (Copus et al., 2008). Numerous studies and comparative research elaborate aspects of the innovative and technological capacities of individual regions and countries. According to the comparative studies, innovation activity in Europe has in the past been concentrated in regions in Northern and Central Europe, i.e. in the countries and regions that are also more developed in terms of economy and education; countries such as Finland, France, Germany, the Netherlands, Sweden and the UK traditionally rank high when national and regional innovative or technological capacities are compared (Hollanders, 2007; European commission, 2009).

In line with the above, Pinto (2009) stated that according to patent and R\&D statistics the most innovative regions in the EU are found in Austria, Germany, the Netherlands and Sweden, as well as disadvantaged regions in Southern Europe. This tendency is diminishing and the southern parts of Europe are becoming increasingly competitive when it comes to innovation (Moreno et al., 2005), but peripheral and rural areas are still at a technological disadvantage when the geography of innovation is concerned (Tödtling \& Trippl, 2005; Coronado et al., 2008). There are also significant differences in the regional innovation policies of European countries (Prange, 2008). These differences can explain to a certain degree the cross-country variation in the innovation performance of European regions. 
Hinloopen (2003) studied the innovation performance of selected European countries, concluding that there are differences in the innovation-related environments of countries: some (Germany, Italy and Spain) yield greater commercial output from innovation-related input than expected and some less (Denmark and Sweden). Thus, innovation input does not always lead to successful outcomes (see also Zabala-Iturriagagoitia et al., 2007). Furthermore, it has to be noted that the mechanism responsible for economic performance may be different in each country and region (Rutten \& Boekema, 2005). Different social, political and institutional conditions lead to different reactions to innovation. Some regions exhibit stronger (innovation prone) and some exhibit weaker (innovation averse) than expected economic growth relative to their R\&D activity, i.e. some areas are more successful than others in transforming R\&D into actual economic growth (Rodríguez-Pose, 1999). Recently in Europe this has included the discussion of two compounding innovation paradoxes. A R\&D paradox, where the fast growth rate of innovation inputs does not produce high gross domestic product (GDP) growth, and a regional innovation paradox. The $R \& D$ paradox is related to high-tech societies, where an increasing amount of $\mathrm{R} \& \mathrm{D}$, due to the already high level of sophistication, is needed in order to produce 'something new' in fast growing sectors (Ejermo et al., 2011). The regional innovation paradox describes the contradictions between the need and aspiration for greater public spending on innovation in lagging regions, and their relatively lower capacity to absorb those funds into innovation when compared with more advanced regions (Oughton et al., 2002).

The second main element in empirical investigation concerns educational attainment, which is viewed here as a workforce characteristic related to education, knowledge and skills, as described in previous literature on human capital (e.g. Alquézar Sabadie \& Johansen, 2010). The importance of human capital has been debated, for example, by Florida (2002) who suggested an alternative concept, creative class, supposedly functioning better than the more traditional measures on human capital. Florida's views have aroused a substantial amount of criticism arguing that creative class is only another name given to what is still essentially human capital (Glaeser, 2005). Whatever the term used to describe the presence of educated human capital, previous studies have emphasised that it bolsters the innovative output of regions and creates greater economic activity, and that this human capital is highly concentrated at the regional level (Berry \& Glaeser, 2005; Ewers, 2007). The role of education (and training) is increasingly viewed as the development policy target that has the most potential to create economic growth (de Bruijn \& Lagendijk, 2005); however, the logic behind the causal relationship between highly skilled labour and economic growth has been criticised as blurred and undefined (e.g. Krueger \& Lindahl, 2001; Markusen, 2006). The importance of education hardly leaps out of cross-country data, and, therefore, greater attention should be paid to empirical frameworks and their interpretation and to the examination of economic development across regions of those countries with reliable data (see Krueger \& Lindahl, 2001; Rodríguez-Pose \& Tselios, 2011).

Despite these criticisms of the causal effects, there is a growing body of literature discussing the positive effects of educated human capital on the innovativeness and economic development of 
nations and regions. Accordingly, Ewers (2007) states that the presence of skilled human capital fosters innovation and generates greater economic activity. Empirical studies confirm this, as it has been shown that the higher the investment of a society in the quality of education and the higher the educational level of a region, the higher the innovation activity output of that region (Varsakelis, 2006; Gössling \& Rutten, 2007). Furthermore, for regions the negative effect of having a large, less educated population is a key factor in explaining poor innovative performance (Bilbao-Osorio \& Rodríguez-Pose, 2004). Thus, some researchers have concluded that, although there is no direct causality between educated human capital and economic growth, education positively affects economic development through innovation and technological progress (see Strulik, 2005). The more straightforward connection between education and economic development has also been documented (see e.g. Tsai et al., 2010). However, Simonen and McCann (2008) claim that local human capital inputs are never positively related to innovation, whereas human capital from other regions may be important. It remains debatable whether or not educated (local) human capital has an impact, direct or indirect, on the economic growth of nations and regions.

As discussed, the results of previous studies are manifold and in some cases contradict one another. Some authors claim that human capital, specifically education, is the cornerstone of economic growth (or at least influences it through its significant role in innovation creation). Other authors, however, highlight the central importance of $\mathrm{R} \& \mathrm{D}$, patents and ultimately innovation, but the rate that nations and regions are able to turn innovation into economic well-being differs. By the same token, the development level of a given nation or region is bound to have an impact on their innovative and educational activities. Therefore, in summation, it can be stated that, studies often related to clusters or innovation systems, on innovative capacity, educational attainment and economic development have yet to reach a concencus on the direction of the causal links between those three dimensions. This paper empirically contributes to this extensive literature through analysing the causal relations between the studied dimensions and by presenting detailed country- and region-wise information about their geographical variations in the context of the enlarged EU.

\section{Data and Methods Consideration and Limitation}

The data was collected from Eurostat, considered to be the most comprehensive and reliable source of statistics when dealing with comparable data at the NUTS-0 (national) and NUTS-2 levels in the EU, regional databases. Furthermore, the data sets are readily available to everyone, which means that the analyses used in this study are repeatable and updatable. The data covers the whole EU, the countries $(n=27)$ and NUTS-2 $(n=267)$ regions of the EU, with the exception of French overseas departments. The variables are normalised according to population to avoid distortions created by differences in region size. Due to the lack of comparable regional data from the new member states prior their EU 
entry, the data is collected from the years 2003-2007, to allow comparison in relation to the proposed catching up in process (see Moreno et al., 2005), for the geographical analysis and from the years 1998-2008 for the Granger causality test (whole EU). Some individual NUTS-2 regions in different countries have missing data in the statistics. The missing data was calculated by using the data of the NUTS-1 region to which they belong and the population of the NUTS-2 in question, thus decreasing the actual variation in the dataset. The individual missing values were replaced by moving averages. The percentage of missing data points in the original data set is approximately $5 \%$.

Empirically innovative capacity is treated in the following way: business sector R\&D expenditure (per thousand inhabitants) and patent applications [to the European Patent Office (EPO) per million inhabitants] were used to rank the countries and regions (average standings). Similar approach was used in the case of educational attainment and economic development. Business sector R\&D measures were used for their better data availability, and since they account for the majority of the R\&D conducted in the EU. These measures have their drawbacks as innovation indicators, mainly because they are not necessarily related to successful innovation outputs (e.g. Fagerberg, 2005; Ratanawaraha \& Polenske, 2007), i.e. R\&D and patent measures are proxy indicators of innovation. Furthermore, there are additional indicators related to $R \& D$ and patent statistics (for example to the size structure of the firms) that can condition both the R\&D expenditures and patents in a given region. Still, several studies have shown that they function relatively well as indicators of innovation (Ma \& Lee, 2008; Sterlacchini, 2008). As the patent application data used here is from the EPO, the conventional problems with the differences in the requirements of patentability on national and regional levels do not apply here. There are similar problems with the empirical treatment of educational attainment (and human capital) as, according to Wößmann (2003), human capital is, alas, mostly poorly proxied. Thus, data on the formal education of the workforce still provides the best available proxy information on the level of (educated) human capital on national and regional scales as other measures either suffer from poor data availability or include flow variables that poorly represent the current situation (Teixeira \& Fortuna, 2010). Measures related to the workforce, its educational level (population with tertiary education per thousand inhabitants) and participation in lifelong learning (per thousand inhabitants) were, thus, used as indicators of educational attainment.

One could also criticise the selection of GDP as the variable depicting economic development on the grounds of its frequently stated drawbacks (mainly the economic activities that cannot be accounted for by gross domestic product), but it is still the most commonly used and widely accepted measure of the wealth of an economy. Thus, GDP per capita was used together with average household incomes (measured per capita) as the basis for describing economic development. Additionally, the variable selection is based heavily on data availability, which is often the case when researchers are working with pre-compiled statistics.

The Granger (1969) causality test is a useful tool in business and economic research (see Mansson et al., 2011), as the dependence of variables is rarely instantaneous, but very often one variable 
responds to another after a lapse of time (lag) (Gujarati, 1978). The importance of the use of time lags in innovation studies, i.e. the notion that the benefits from innovation inputs rather than being instantaneous are realised after a time lag, has been brought up before (e.g. Lachenmaier \& Rottmann 2011; Makkonen, 2011). The Granger causality test is founded upon these lags between different variables i.e. to the fact that events in the past can cause events to happen today while future events cannot (Mansson et al., 2011). As Thurman and Fisher (1988) state the notion is simple: 'if lagged values of $\mathrm{X}$ help predict current values of $\mathrm{Y}$ in a forecast formed from lagged values of both $\mathrm{X}$ and $\mathrm{Y}$, the $\mathrm{X}$ is said to Granger cause $\mathrm{Y}^{\prime}$. Thus the chosen method fits well with the purpose of this paper to determine the direction of causality. The method is in frequent use (e.g. Battisti et al., 2010; Graham et al., 2010; Tselios, 2011) and according to the comparison of theory and results (of this and above mentioned studies) it can be considered as a valid and reliable test for this study.

Granger causality test has also been criticised to be more a measure of temporal relatedness than genuine causality (Thurman \& Fisher, 1988). Furthermore, it does not take into account the possibility of a third (or more) process as a common driver behind both, $\mathrm{X}$ and $\mathrm{Y}$. There are also problems related to the number of lagged terms included (Graham et al., 2010). The excessive inclusion of lags does not produce new information, but introduces strong multicollinearity in the estimation, which according to Mansson et al. (2011) leads to the over-rejection of the true null hypothesis. On the other hand, the use of short time-series and only a few lags may lead to a poor econometric specification of the relationship between the variables. The lag choice of two years is used here due to the short time series available. A more expansive set of panel data would have allowed the testing of different lag structures, as the effects may take longer than two years to manifest themselves. Thus, while short time-series even annual lags are applicable (Tselios, 2011), the uncertainty of the right lag structure, as well as the arguments of 'genuine' causality, remain as limitations of this study.

\section{Results: Causal Relations and Geographical Variations}

The analyses follows street step path: first the EU level aggregate Granger causality is examined in order to obtain the most significant lag variables to explain variable interrelations (Table 1). The analysis moves then to regional scales including countries. The connections from education to patents and from lifelong learning to $R \& D$ have the most significant causal relationships (at 0.01 level). The causality from education to $R \& D$ and all relations from economic development to innovation indicators belong to the second significance group (at 0.05 level). Therefore, educational attainment and economic development Granger causes innovative capacity. However, there are indications of significant Granger causalities also from innovation indicators to economic development indicators: most notably the relationship from patents to income. Thus, the link between innovative capacity and 
economic development is bidirectional. On the contrary the Granger causality seems to run one-way from education indicators to economic development i.e. from lifelong learning and education to GDP. The use of lags in the case of overall EU data indicates stable and significant connections between the variables. Educational variables (education and lifelong learning) significantly contribute to $\mathrm{R} \& \mathrm{D}$

Table 1. Granger causality test statistics (lags: 2).

\begin{tabular}{lclc}
\hline Null hypothesis: & F-statistics & Null hypothesis: & F-statistics \\
\hline Education --> Patents & $45.56(*))$ & R\&D --> GDP & 5.13 \\
Lifelong learning --> R\&D & $28.56(* *)$ & Education --> Income & 4.84 \\
Education --> R\&D & $13.02(*)$ & R\&D --> Lifelong learning & 4.45 \\
GDP --> Patents & $12.63(*)$ & GDP --> Education & 3.51 \\
Lifelong learning --> GDP & $9.80(*)$ & Lifelong learning --> Income & 3.20 \\
Income --> Patents & $9.65(*)$ & Income --> Lifelong learning & 2.86 \\
Patents --> Income & $8.42(*)$ & Patents --> Education & 1.89 \\
Education --> GDP & $8.34(*)$ & R\&D --> Income & 1.50 \\
GDP --> R\&D & $8.11(*)$ & R\&D --> Education & 1.36 \\
Income --> R\&D & $7.62(*)$ & GDP --> Lifelong learning & 0.86 \\
Lifelong learning --> Patents & 6.23 & Patents --> GDP & 0.72 \\
Income --> Education & 5.87 & Patents --> Lifelong learning & 0.40 \\
\hline \multicolumn{2}{c}{ 1 The reported F-statistics are the Wald statistics. } \\
\end{tabular}

activities (including patents), but the overall impact on economic development is less evident. However, based on Granger causalities education and lifelong learning are more significant contributors to GDP compared to R\&D and patents. The bidirectional link between innovative capacity and economic development can be verified, although in light of the evidence shown here it seems that the Granger causality is stronger from economic development to innovative capacity. It thus seems that in the EU firms, regions and nations are investing more on R\&D and producing more inventions, but do not gain from it, in economic terms, as significantly. This notion gives evidence of the existence of innovation paradoxes in the EU.

The countries with the best innovative capacity are those with high levels of economic development (Figure 1) as indicated by the conducted Granger tests. The most innovative (in terms of capacity) and economically developed countries of the EU Scandinavian and Benelux countries together with Germany, Austria, France, the United Kingdom and Ireland, while the new member countries of Eastern Europe lag clearly behind in terms of their innovative and economic capabilities. The links between educational attainment and both innovative capacity and economic development are weaker in the country comparison, although most of the top ranking countries in the educational attainment ranking also appear in the top ten rankings of innovative capacity and economic development (Appendix).

Figures 2 and 4 are divided with quadratic segmentation into high-high, high-low, low-high and low-low categories. Particularly interesting areas are those with a high economic development but low 
innovation index rank, and those with a low economic but high innovative capacity rank. The locations that closely follow the hypothesised fit line in both extremes are commonly identified innovation clusters or less developed areas within the EU. Ireland underwent an economic 'boom' between the years 2003 and 2007, which coincided with significant improvement in the educational attainment index. However, Ireland (and to a some extent Cyprus, but this more probably due to the

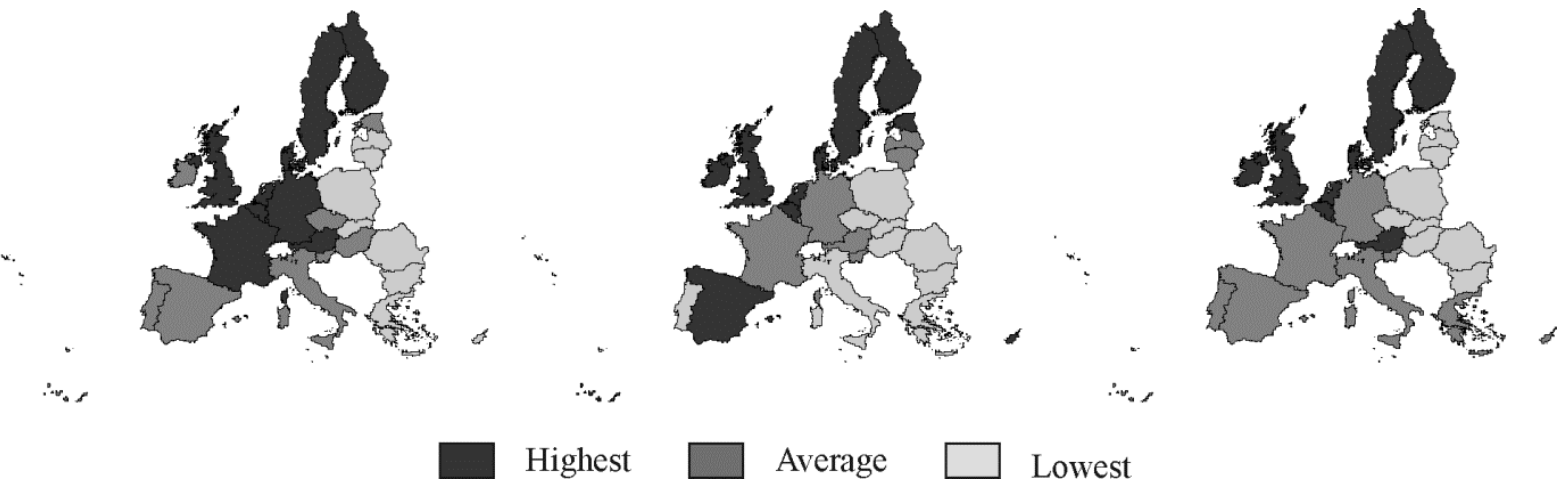

Figure 1. Innovative capacity (left), educational attainment (centre) and economic development (right) of EU countries in 2007.

fact that the source of income data for Cyprus was not consistent with that of other countries) is an exception to the rule of the interconnection of innovative capacity and economic development, as it scores considerably lower in the innovative capacity index compared to the economic development index especially in 2007. The good contemporary economic situation of Ireland could be explained by Barry (2007), who has stressed the importance of a high proportion of science and engineering graduates among young adults in Ireland and the foreign direct investments attracted by certain hightech sectors. Recent events have, however, shown that the rapid economic growth of Ireland was not founded on a sustainable basis. On the contrary, Finland ranks high in both innovative capacity and educational attainment, but lower in economic development (Germany also ranks high on innovative capacity but low on economic development especially in 2007) (Figure 2). This is related to the significant investment in and endorsement of innovative activities by Finnish authorities, which, it seems, have not had as impressive economic yields as envisaged (see also Sabel \& Saxenian, 2008).

As the number of observation units increases the regions do not fall as neatly into the hypothesised fit line of economic development and innovative capacity as Figure 3 indicates: there is much more 

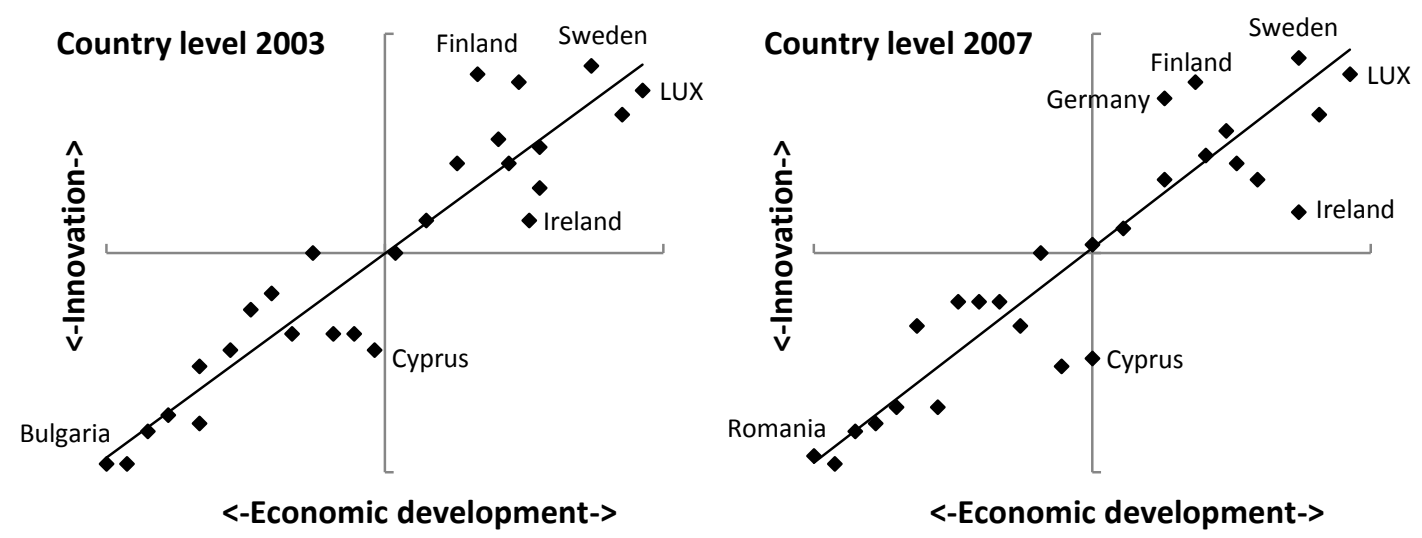

Figure 2. Innovation (in terms of capacity) and economic development rankings (averages) of EU countries in 2003 and 2007.

dispersion in the rankings of NUTS-2 regions. Still, although less evident than in the case of countries, the link between innovative capacity and economic development is clear also at the NUTS2 level (Figure 4). The best examples of the interconnection between educational attainment and innovative capacity as well as economic development are the Capital Region of Denmark (DEN) and Stockholm (SWE) (Appendix).

Inner London (UK), Eastern Scotland (UK) and Åland (FIN) (Figure 4) stand out as anomalies. Åland is economically well-off and an exceptional region in that it is an autonomous part of Finland, where the leisure/travel industry is an important source of income. However, it features low regional levels of innovative capacity, as tourism does little to contribute to innovative capacity, in terms of R\&D and patents, as indicated by Hjalager (2002). The same applies to some extent to the Balearic Islands. The good performance of London on the economic development ranking despite its poor innovative capacity ranking is counterbalanced by an exceptionally good educational attainment ranking (average score $=7$ ) (see also Wood, 2009). The low innovation ranking score of Eastern Scotland in 2007 coincides with a steep drop in business sector R\&D expenditure. A contrasting exception is that of Berlin (GER), which ranks highly in the innovative capacity index, but lower in 


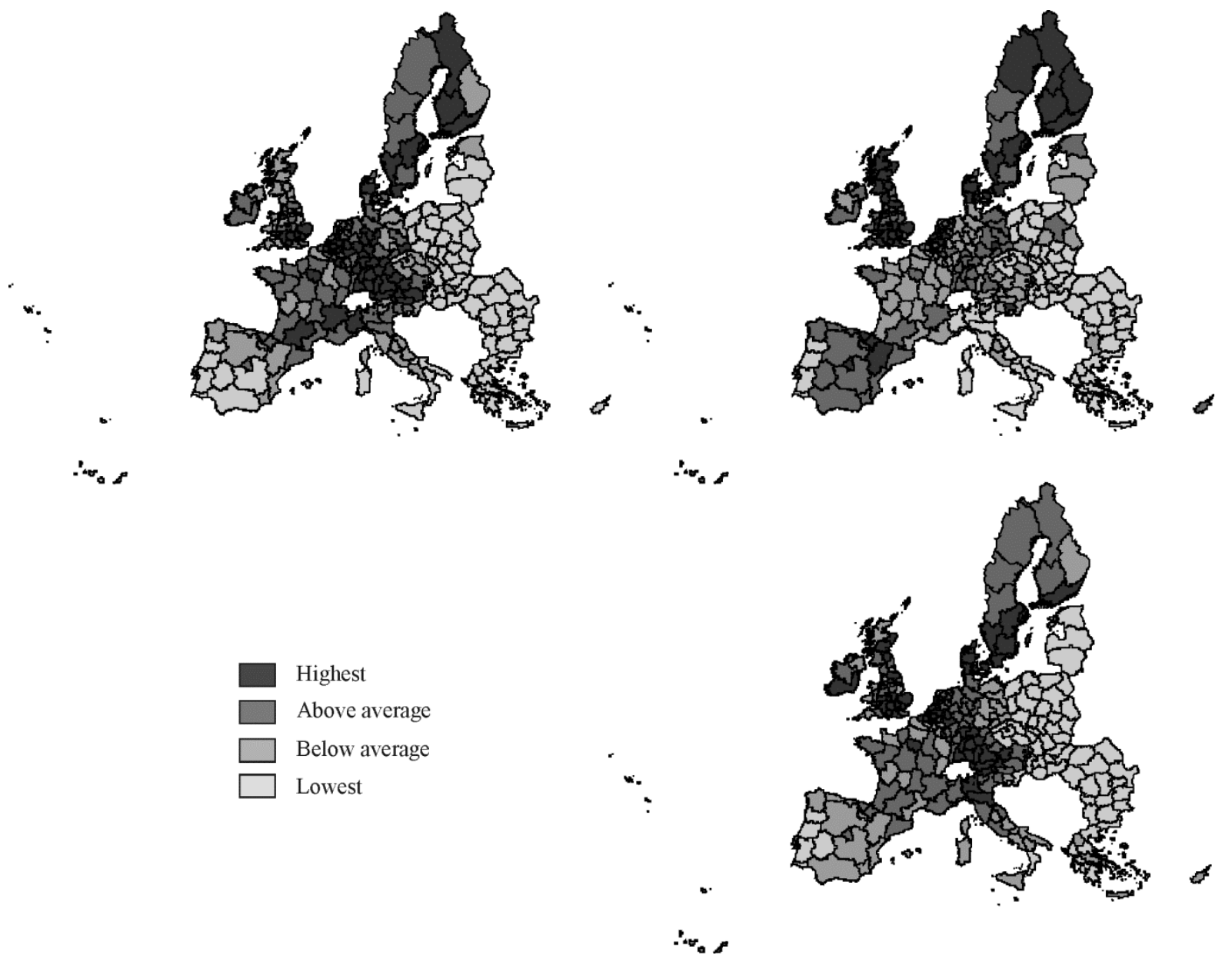

Figure 3. Innovative capacity (top left), educational attainment (top right) and economic development (bottom left) of NUTS-2 regions of the EU in 2007.

economic development. One explanation for this could be that Berlin as a region (including east and west Berlin) has not yet stabilised its economic base and suffers from the loss of traditional manufacturing industries, resulting in economic weakness and growing disparities between the core of the region, the city of Berlin, and its peripheries (Kujath, 2005). However, several German (also other countries e.g. Finland), regions rank high in the innovation index, due to the ever increasing investment in $\mathrm{R} \& \mathrm{D}$, but lower in the economic development index. The $\mathrm{R} \& \mathrm{D}$ paradox described by Ejermo et al. (2011) is confirmed to also concern other highly developed EU countries and regions. Investing heavily on $R \& D$ does not guarantee fast economic growth when the society has already crossed a certain threshold in $R \& D$. Accordingly, many lagging regions first require the necessary absorptive capacity to gain from the rising R\&D expenditure (see Oughton et al., 2002).

Additionally, many of the NUTS-2 regions of North Italy (e.g. the semi-autonomous Aosta Valley and autonomous provinces of South Tyrol and Trento) perform much better in economic terms than their standings on the innovative capacity index would suggest (Figure 4). This is probably due to 

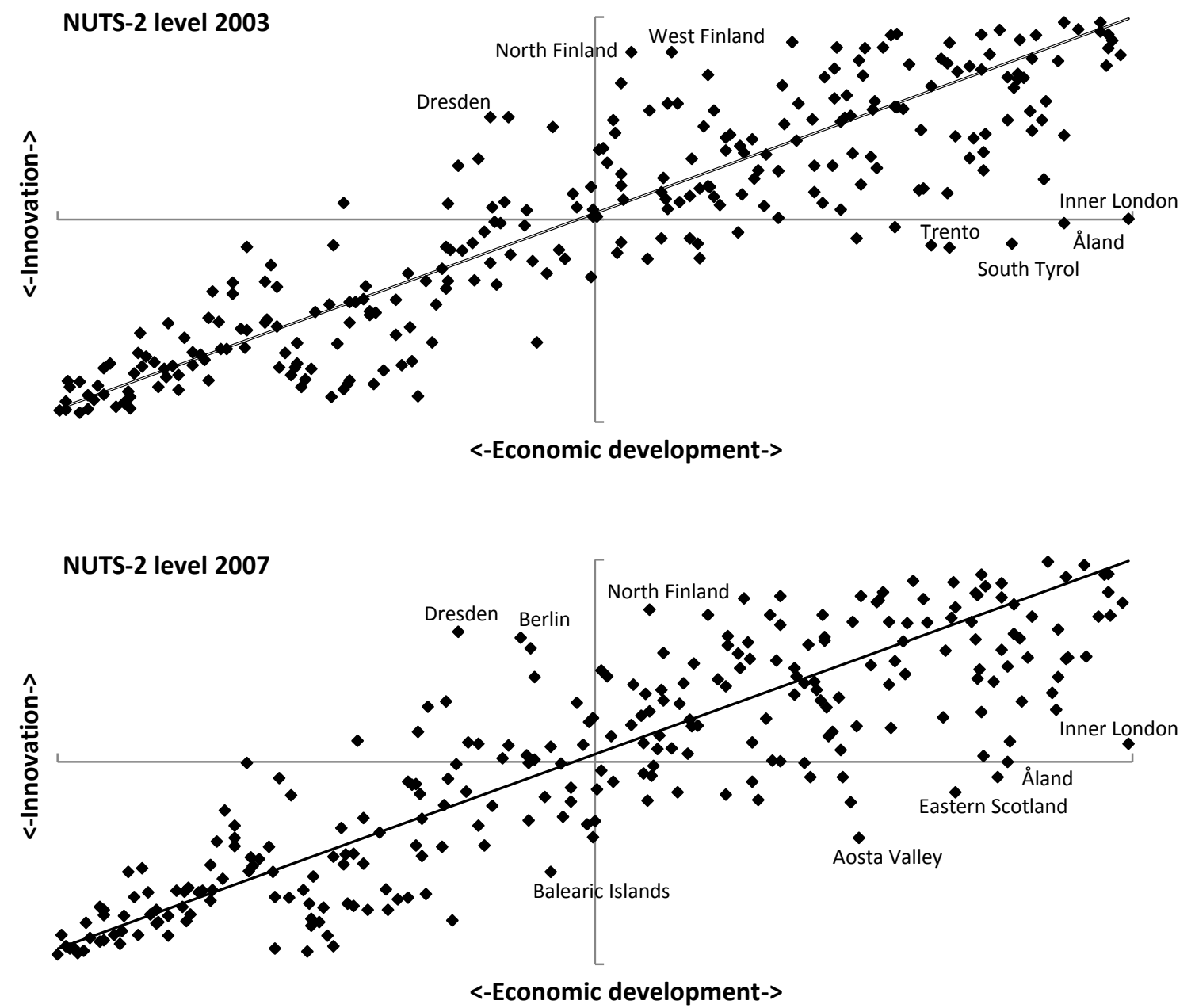

Figure 4. Innovation (in terms of capacity) and economic development rankings (averages) of NUTS2 regions in 2003 and 2007.

their long tradition of industry (Iammarino, 2005). Old, well established industrial clusters commonly become less innovative as time passes (see e.g. Pouder \& St. John, 1996). Furthermore, Evangelista et al. (2002) have shown that only a few of the Italian regions can be designated as proper innovation systems, as the innovative activities in the rest of the regions are based on informal technological linkages inside a coherent and cohesive industrial environment.

At the country level the changes in the ranking between the years 2003 and 2007 are moderate. However, at the regional level there is interesting development underway. As to these changes in the studied dimensions in the time period of 2003-2007 it can be stated that Spanish regions have done exceedingly well in increasing the percentage of adult population participating in lifelong learning (Figure 3), whereas most of the capital regions of Eastern Europe (regions around Bratislava [SLV], Bucharest $[\mathrm{ROM}]$ and Prague [CZE]) and some South European regions such as Basque Country (SPA) are in economic terms among the fastest growing NUTS-2 regions in the EU. Since the data does not cover the most recent years, impacts of the current financial crisis of the EU are not included. 
However, in Scandinavian countries at least, levels of R\&D and educational expenditures remain relatively stable even when their GDP growth decreases. By contrast, in some other European countries, levels of R\&D and educational expenditures decrease more in line with their GDP (see Filippetti \& Archibugi, 2011).

\section{Synthesis and Discussion}

The conducted analysis on innovative capacity, educational attainment and economic development lays basis for the broader context of the paper, as the identified leading regions and countries are examples not only of 'containers' of location based activity, but also of issues of regional disparities that are fundamental to the policies and balancing goals, of which there is a long tradition in the EU. A summary of the empirical results is presented in Figure 5 as a schematic. The figure shows the direction of causations that exist between the studied dimensions. The relationships from educational attainment and economic development to innovative capacity and from educational attainment to economic development are the strongest, but to a certain degree the flows also work in both ways as e.g. innovative capacity does have an impact on the economic development.

The first implication of the results (Figures 1-5) concerns the recognition of spatial generalisations and national variations in NUTS-2 classification. The analysis indicated that the national level, as an observation unit, gives a distorted picture of the true heterogeneity of innovative capacity and educational attainment in the EU due to extensive differences within countries. Even the smaller regional units observed have their weaknesses, as it is expected that some of the geographically larger NUTS-2 regions give a seemingly homogenous picture of the entire region (also Pinto, 2009). As an

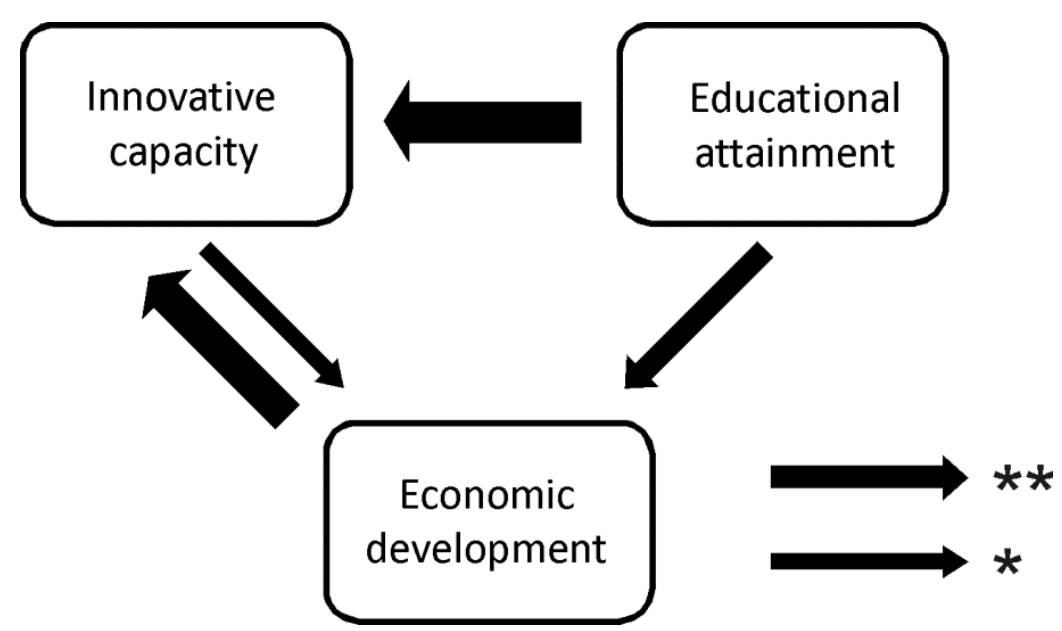

Figure 5. The Granger causality relationships between the studied dimensions [the thickness of the arrows represents the number and significance of Granger causalities between these three concepts (see Table 1)]. 
example, in Finland the NUTS-2 regions are relatively large compared to regions of the other EU members states and, therefore, the more peripheral parts of Finland can appear to be highly innovative and relatively well developed; however, the truth is that the core regions, i.e. larger cities, are usually the drivers of innovation and the more peripheral parts are at a disadvantage when it comes to innovation and economic development (also Jauhiainen 2008). The same applies for smaller member countries such as the Baltic States (Estonia, Latvia, and Lithuania), where the whole of the country acts as a NUTS-2 region: no variation within these countries can be detected from the data used in this study. As Titze et al. (2011) indicated, regions rarely have as similar production structures as their national averages might suggest. Thus, to study the full range of differences of the innovative and educational capacities of the EU, the use of smaller regional levels of observation would be ideal. This is a challenge for future studies to take on, including the methodological problem of how to successfully implement smaller study regions and simultaneously taking into account the possible limitations related to spatial autocorrelation (see Acs et al., 2002). These policy implications therefore particularly concern the question of the spatial scale on which observations are being made. Innovative capacity is a result of learning organisations and skilled individuals. Therefore, innovation process recognition requires micro-level case data and understanding of individual processes and circumstances that have existed behind the breakthrough innovations. The 'opening of the black box' is recognised as one of the challenges underlying the macro-level spatial observations.

The second implication concerns the recognition, identification and creation of development strategies concerning key elements in innovative driven growth. The existing challenge of strategy (and 'best practice') transfer from one location to another remains if a critical understanding of the means by which such transfer can successfully occur is missing in the first place (Bristow, 2010). This notion is related to the visible (Figures 2 and 4) North-South and East-West divides between strong and weak nations and regions that exist in the EU. This fragmentation has impacts on the EU's regional policy instruments and consortium structures: competitive research funding reflects similar balancing goals both on EU and national levels, as Jauhiainen (2008) indicated, and causes a situation in which the well-established and recognised locations (in terms of e.g. university research) gain relatively more resources than locations where units do not have the same ability to compete in funding. This is a common practice among the consortium partners: the stronger recognised units often ally themselves with those with similar strengths (also Must, 2010). Thus, although in some indicators there is an evident catch up in progress, the argument made by Armstrong and de Kervenoael (1997) over a decade ago concerning the problematic of divergence and convergence development in the EU still remains, as indicated by the fragmentation of the observed regional innovation and economic centres within the EU (Figures 2 and 4).

In terms of policy options, the question remains of how to incorporate good experiences from one side of Europe into another with different locational strengths and production traditions. Accordingly, 
benchmarking allows regions and countries to improve their practices through comparison with toprated territories, but the best practices cannot be replicated as such: the particular characteristics of the regions and countries have to be taken into account before outright application (Zabala-Iturriagagoitia et al., 2007; Inkinen \& Suorsa, 2010). Thus, in a porterian sense it is well advised to enhance the existing basic industrial structure and at the same time promote new potential industries and companies within the reach of present and prospective locational and infrastructural requirements (Mikkonen, 2002).

The third implication of the analyses concerns the horizontal and vertical collaborations between the public and private sectors: drawing from innovation systems literature, the most sensible action seems to be the strengthening of the ties between the private and public organisations to support the possibilities stemming from heightened cooperation, e.g. in the form of Public-Private Partnerships (Latteman et al., 2009). Furthermore, both at the European and national level, it would be of importance to alleviate the considerable differences in the studied dimension at the regional level in order to meet the territorial cohesion goals promoted by the European Commission (2010). In particular, the strengthening of an educational system and endorsement of life-long learning should be among the priority objectives of nations and regions striving for economic and innovative success. Benchmarking for better performance in the dimensions under study here is highly advisable; one popular example is that of the Nordic schooling system, which lays the foundation for good performance in educational attainment and innovative capacity. This impression is further highlighted by encouraging examples, e.g. Sweden and Denmark, from the geographical comparison of high educational and innovation levels.

\section{Conclusions}

This study examined the connection between innovative capacity, educational attainment and economic development in Europe. From the analyses in this paper, it can be concluded that innovative capacity, educational attainment and economic development are interconnected with varying degrees indicated in Figure 5. According to the results educational attainment leads to higher innovative capacity and economic development. These relationships are to a certain degree intertwined and bidirectional. Accordingly, the most innovative (in terms of capacity) countries and regions are mainly those with higher economic development and educational levels. The regional analyses show that the majority of the highest ranking regions are located in the core areas of Western and Northern Europe. The best examples of this interconnectedness can be found in the commonly identified (e.g. European Commission, 2009) Denmark and Sweden. In general terms, the core is stronger, whereas the more remote locations in Southern and Eastern Europe occupy the lowest ranking positions. Although catching up in some indicators, as predicted by Moreno et al. (2005), in the overall situation 
the countries of Southern Europe and the new member countries and regions of Eastern Europe still lag behind in terms of innovative capacity, educational attainment and economic development. However, the analysis indicated large variations in the cross-references of innovative capacity and economic development not consistent with the stylised geographical generalisation above: there are some regions (such as Åland and Inner London) in Western and Northern Europe with high economic development condition but a low innovative capacity index, as well as regions with high innovative capacity index but low economic index rankings thus bringing forth the existence of innovation paradoxes discussed by Ejermo et al. (2011) and Oughton et al. (2002) in many societies. The obtained results have significance for policy development and understanding of current regional structure behind innovation capacity.

The study indicated also the loss of information when moving from a smaller spatial scale to a larger one. The territorial units analysed in this paper are suitable for country- and region-wise comparisons. However, national averages function poorly as indicators of regional performance. This notion is evident also in this study as the residuals are smaller on the country level and diversity increases in the NUTS-2 level. In addition, the regionalisation of the studied phenomena indicated that high ranking nations also have regions that are not that successful. The heterogeneity of the studied dimensions inside the EU is undermined if concentrating only on the national level: even the NUTS-2 regions are in some cases geographically large and known to have considerable variations, i.e. cores and peripheries, within them. These notions highlight the importance of the use of smaller units of observation. Accordingly, the benchmarking of territorial practices, in a way that takes into account the local particularities, is advisable: perhaps suitable units for future regional analysis could be found by looking at the literature on clusters or regional innovation systems.

It is important to bear in mind that while economic development accounts for much of the quality of life in a country it is not a synonym for well-being. Thus, a fruitful direction for further studies would be to incorporate different social factors, which contain information beyond economic measures, into the analyses. This would allow a more detailed discussion about the well-being of the population in a given region. However, doing so requires qualitative analyses and the recognition of socio-cultural issues concerning economic and regional development. Accordingly, further investigation into the interrelation between innovation performance and the well-being of the population is required.

\section{Acknowledgements}

This research is part of the Academy of Finland funded project 127213. The authors thank Gareth Rice and two anonymous reviewers for their constructive comments for improving the paper and Maria Salonen for her help with the mapmaking. 


\section{References}

Acs, Z., Anselin, L. \& Varga, A. (2002) Patents and innovation counts as measures of regional production of new knowledge, Research Policy, 31, pp. 1069-1085.

Alquèzar, J., Sabadie, J. \& Johansen, J. (2010) How do national economic competitiveness indices view human capital, European Journal of Education, 45, pp. 236-258.

Armstrong, H. \& de Kervenoael, R. (1997) Regional economic change in the European Union, in J. Bachtler \& I. Turok (Eds) The Coherence of EU Regional Policy: Contrasting Perspectives of the Structural Funds, pp. 29-47. London: Regional Studies Association and Jessica Kingsley Publishers.

Balzat, M. \& Hanusch, H. (2004) Recent trends in the research on national innovation systems, Journal of Evolutionary Economics, 14, pp. 197-210.

Barry, F. (2007) Third-level education, foreign direct investment and economic boom in Ireland, International Journal of Technology Management, 38, pp. 198-218.

Battisti, G., Mourani, A-G. \& Stoneman, P. (2010) Causality and a firm-level innovation scoreboard, Economics of Innovation and New Technology, 19, pp. 7-26.

Berry, C. \& Glaeser, E. (2005) The divergence of human capital levels across cities, Papers in Regional Science, 84, pp. 407-444.

Bilbao-Osorio, B. \& Rodríguez-Pose, A. (2004) From R\&D to innovation and economic growth in the EU, Growth and Change, 35, pp. 434-455.

Boschma, R. (2005) Proximity and innovation: A critical assessment, Regional Studies, 39, pp. 61-74.

Bristow, G. (2010) Critical Reflections on Regional Competitiveness: Theory, Policy, Practice. London: Routledge.

Copus, A., Skuras, D. \& Tsegenidi, K. (2008) Innovation and peripherality: An empirical comparative study of SMEs in six European Union member countries, Economic Geography, 84, pp. 51-82.

Coronado, D., Acosta, M. \& Fernández, A. (2008) Attitudes to innovation in peripheral economic regions, Research Policy, 37, pp. 1009-1021.

Crescenzi, R. \& Rodríguez-Pose, A. (2011) Innovation and Regional Growth in the European Union. Berlin: Springer-Verlag.

de Bruijn, P. \& Lagendijk, A. (2005) Regional innovation systems in the Lisbon Strategy, European Planning Studies, 13, pp. 1153-1172.

Doloreux, D. \& Parto, S. (2005) Regional innovation systems: Current discourse and unresolved issues, Technology in Society, 27, pp. 133-153.

Ejermo, O., Kander, A. and Svensson Henning, M. (2011) The R\&D-growth paradox arises in fast-growing sectors, Research Policy, 40, pp. 664-672.

European Commission (2009) European innovation scoreboard 2008. Comparative analysis of innovation performance, PRO INNO Europe Paper, 10.

European Commission (2010) Europe 2020. A Strategy for Smart, Sustainable and Inclusive Growth. Brussels: European Commission.

Evangelista, R., Iammarino, S., Mastrostefano, V. \& Silvani, A. (2002) Looking for regional systems of innovation: Evidence from the Italian innovation survey, Regional Studies, 36, pp. 173-186.

Ewers, M. (2007) Migrants, markets and multinationals: Competition among world cities for the highly skilled, GeoJournal, 68, pp. 119-130.

Fagerberg, J. (2005) Innovation: A guide to the literature, in J. Fagerberg, D. Mowery \& R. Nelson (Eds) The Oxford Handbook of Innovation, pp. 1-26. Oxford: Oxford University Press.

Faggian, A. \& McCann, P. (2009) Human capital, graduate migration and innovation in British regions, Cambridge Journal of Economics, 33, pp. 317-333.

Filippetti, A. \& Archibugi, D. (2011) Innovation in times of crises: National systems of innovation, structure and demand, Research Policy, 40, pp. 179-192.

Florida, R. (2002) The Rise of the Creative Class: And How It Is Transforming Work, Leisure, Community and Everyday Life. New York: Basic Books.

Glaeser, E. (2005) Review of Richard Florida's The Rise of the Creative Class, Regional Science and Urban Economics, 35, pp. 593-596.

Graham, D., Melo, P., Jiwatanakulpaisarn, P. \& Noland, R. (2010) Testing for causality between productivity and agglomeration economies, Journal of Regional Science, 50, pp. 935-951.

Granger, C. (1969) Investigating causal relations by econometric models and cross-spectral methods, Econometrica, 37, pp. 424-438.

Gujarati, D. (1978) Basic Econometrics. Tokyo: McGraw-Hill Kogakusha.

Gössling, T. \& Rutten, R. (2007) Innovation in regions, European Planning Studies, 15, pp. 253-270. 
Hinloopen, J. (2003) Innovation performance across Europe, Economics of Innovation and New Technology, 12, pp. $145-161$.

Hjalager, A-M. (2002) Repairing innovation defectiveness in tourism, Tourism Management, 23, pp. $465-474$.

Hollanders, H. (2007) 2006 European Regional Innovation Scoreboard. Maastricht: MERIT.

Iammarino, S. (2005) An evolutionary integrated view of regional systems of innovation: Concepts, measures and historical perspectives, European Planning Studies, 13, pp. 497-519.

Inkinen, T. \& Suorsa, K. (2010) Intermediaries in regional innovation systems: High-technology enterprise survey from Northern Finland, European Planning Studies, 18, pp. 169-187.

Jauhiainen, J. (2008) Regional and innovation policies in Finland: Towards convergence and/or mismatch, Regional Studies, 42, pp. 1031-1045.

Krueger, A. \& Lindahl, M. (2001) Education for growth: Why and for whom, Journal of Economic Literature, 39, pp. 1101-1136.

Krugman, P. (2011) The new economic geography, now middle-aged, Regional Studies, 45, pp. 1-7.

Kujath, H.J. (2005) Restructuring of the metropolitan region of Berlin-Brandenburg: Economic trends and political answers, Geographica Polonica, 78, pp. 117-136.

Lachenmaier, S. \& Rottmann, H. (2011) Effects of innovation on employment: A dynamic panel analysis, International Journal of Industrial Organization, 29, pp. 210-220.

Lattemann, C., Stieglitz, S., Kupke, S. \& Schneider, A-M. (2009) Impact of PPPs to broadband diffusion in Europe, Transforming Government: People, Process and Policy, 3, pp. 355-374.

Lundvall, B-A. \& Maskell, P. (2000) Nation states and economic development: From national systems of production to national systems of knowledge creation and learning, in G. Clark, M. Feldman \& M. Gertler (Eds) The Oxford Handbook of Economic Geography, pp. 353-372. Oxford: Blackwell.

Ma, Z. \& Lee, Y. (2008) Patent application and technological collaboration in inventive activities: 1980-2005, Technovation, 28, pp. 379-390.

Makkonen, T. (2011) Innovation and regional socio-economic development - Evidence from the Finnish local administrative units, Bulletin of Geography. Socio-economic Series, 15, pp. 27-42.

Mansson, K., Sjölander, P. \& Shuruk, G. (2011) A new ridge regression causality test in the presence of multicollinearity, Journal of Regional Development, 3, pp. 1-15.

Markusen, A. (2006) Urban development and the politics of a creative class: Evidence from a study of artists, Environment and Planning A, 38, pp. 1921-1940.

Maskell, P. \& Malmberg, A. (1999) Localised learning and industrial competitiveness, Cambridge Journal of Economics, 23, pp. 167-185.

Mikkonen, K. (2002) The competitive advantage of regions and small economic areas: The case of Finland, Fennia, 180, pp. 191-198.

Molina-Morales, F.X. \& Mas-Verdu, F. (2008) Intended ties with local institutions as factors in innovation: An application to Spanish manufacturing firms, European Planning Studies, 16, pp. 811-827.

Moodyson, J., Coenen, L. and Asheim, B. (2008) Explaining spatial Patterns of innovation: Analytical and synthetic modes of knowledge creation in the Medicon Valley life-science cluster, Environment and Planning A, 40, pp. 1040-1056.

Moreno, R., Paci, R. \& Usai, S. (2005) Geographical and sectoral clusters of innovation in Europe, Annals of Regional Science, 39, pp. 715-739.

Must, Ü. (2010) Collaboration in EU Framework Programmes - The case of the social sciences and humanities, Innovation: The European Journal of Social Science Research, 23, pp. 79-83.

Oughton, C., Landabaso, M. \& Morgan, K. (2002) The regional innovation paradox: Innovation policy and industrial policy, Journal of Technology Transfer, 27, pp. 97-110.

Pinto, H. (2009) The diversity of innovation in the European Union: Mapping latent dimensions and regional profiles, European Planning Studies, 17, pp. 303-326.

Porter, M. (1990) The Competitive Advantage of Nations. London: The MacMillan Press Ltd.

Porter, M. (1998) Clusters and the economics of competition, Harvard Business Journal, 1998 (NovemberDecember), pp. 77-90.

Porter, M. (2003) The economic performance of regions, Regional Studies, 37, pp. 549-578.

Pouder, R. \& ST. John, C. (1996) Hot spots and blind spots: Geographical clusters of firms and innovation, The Academy of Management Review, 21, pp. 1192-1225.

Prange, H. (2008) Explaining varieties of regional innovation policies in Europe, European Urban and Regional Studies, 15, pp. 39-52.

Ratanawaraha, A. \& Polenske, K. (2007) Measuring geography of innovation: A literature review, in K. Polenske (Ed) The Economic Geography of Innovation, pp. 30-59. Cambridge: Cambridge University Press.

Rodríguez-Pose, A. (1999) Innovation prone and innovation averse societies: Economic performance in Europe, Growth and Change, 30, pp. 75-105. 
Rodríguez-Pose, A. \& Tselios, V. (2011) Mapping the European regional educational distribution, European Urban and Regional Studies, 18, pp. 358-374.

Rutten, R. \& Bokoema, F. (2005) Innovation, policy and economic growth: Theory and cases, European Planning Studies, 13, pp. 1131-1136.

Sabel, C. \& Saxenian, A. (2008) A Fugitive Success: Finland's Economic Future. Helsinki: SITRA.

Simmie, J., Sennett, J., Wood, P. \& Hart, D. (2002) Innovation in Europe: A tale of networks, knowledge and trade in five cities, Regional Studies, 36, pp. 47-64.

Simonen, J. \& McCann, P. (2008) Firm innovation: The influence of R\&D cooperation and the geography of human capital inputs, Journal of Urban Economics, 64, pp. 146-154.

Sterlacchini, A. (2008) R\&D, higher education and regional growth: Uneven linkages among European regions, Research Policy, 37, pp. 1096-1107.

Storper, M. (2011) From retro to avant-garde: A commentary on Paul Krugman's The New Economic Geography, Now Middle-Aged, Regional Studies, 45, pp. 9-15.

Strulik, H. (2005) The role of human capital and production growth in R\&D-based models of economic growth, Review of International Economics, 13, pp. 129-145.

Teixeira, A. \& Fortuna, N. (2010) Human capital, R\&D, trade and long-run productivity: Testing the technological absorption hypothesis for the Portuguese economy, 1960-2001, Research Policy, 39, pp. 335-350.

Thurman, W. \& Fischer, M. (1988) Chicken, eggs and causality or which came first, American Journal of Agricultural Economics, 70, pp. 237-238.

Titze, M., Brachert, M. \& Kubis, A. (2011) The identification of regional industrial clusters using qualitative input-output analysis (QIOA), Regional Studies, 45, pp. 89-102.

Tsai, C-L., Hung, M-C. \& Harriott, K. (2010) Human capital composition and economic growth, Social Indicators Research, 99, pp. 41-59.

Tselios, V. (2011) Is inequality good for innovation, International Regional Science Review, 34, pp. 75-101.

Tödtling, F. \& Trippl, M. (2005) One size fits all? Towards a differentiated regional innovation policy approach, Research Policy, 34, pp. 1203-1219.

Varsakelis, N.C. (2006) Education, political institutions and innovative activity: A cross-country empirical investigation, Research Policy, 35, pp. 1083-1090.

Wood, P. (2009) Service competitiveness and urban innovation policies in the UK: The implications of the 'London Paradox', Regional Studies, 43, pp. 1047-1059.

Wößmann, L. (2003) Specifying human capital, Journal of Economic Surveys, 17, pp. 239-270.

Zabala-Iturriagagoitia, J., Voight, P., Gutiérrez-Gracia, A. \& Jiménez-Sáez, F. (2007) Regional innovation systems: How to assess performance, Regional Studies, 41, pp. 661-672. 


\section{Appendix}

Table 1. The most innovative (in terms of capacity) countries in the EU and their educational capital and economic development rankings (averages).

\begin{tabular}{|c|c|c|c|c|c|c|c|}
\hline 2003 & $\begin{array}{c}\text { Innovative } \\
\text { capacity }\end{array}$ & $\begin{array}{c}\text { Educational } \\
\text { attainment }\end{array}$ & $\begin{array}{c}\text { Economic } \\
\text { development }\end{array}$ & & $\begin{array}{c}\text { Innovative } \\
\text { capacity }\end{array}$ & $\begin{array}{c}\text { Educational } \\
\text { attainment }\end{array}$ & $\begin{array}{c}\text { Economic } \\
\text { development }\end{array}$ \\
\hline Sweden & 2 & 5 & 3,5 & Austria & 6,5 & 12,5 & 8 \\
\hline Finland & 2,5 & 2 & 9 & Netherlands & 7 & 5 & 6 \\
\hline Germany & 3 & 12,5 & 7 & Belgium & 8 & 7 & 7,5 \\
\hline Luxembourg & 3,5 & 15,5 & 1 & France & 8 & 12 & 10 \\
\hline Denmark & 5 & 2 & 5 & United Kingdom & 9,5 & 7 & 6 \\
\hline 2007 & $\begin{array}{c}\text { Innovative } \\
\text { capacity }\end{array}$ & $\begin{array}{c}\text { Educational } \\
\text { attainment }\end{array}$ & $\begin{array}{c}\text { Economic } \\
\text { development }\end{array}$ & & $\begin{array}{c}\text { Innovative } \\
\text { capacity }\end{array}$ & $\begin{array}{c}\text { Educational } \\
\text { attainment }\end{array}$ & $\begin{array}{c}\text { Economic } \\
\text { development }\end{array}$ \\
\hline Sweden & 1,5 & 6,5 & 3,5 & Austria & 6 & 13,5 & 7 \\
\hline Luxembourg & 2,5 & 13 & 1 & Belgium & 7,5 & 8 & 8 \\
\hline Finland & 3 & 1,5 & 8,5 & Netherlands & 8 & 5,5 & 6,5 \\
\hline Germany & 4 & 11 & 10 & France & 9 & 14,5 & 10 \\
\hline Denmark & 5 & 4,5 & 2,5 & United Kingdom & 9 & 7 & 5,5 \\
\hline
\end{tabular}


Table 2. The most innovative (in terms of capacity) NUTS-2 regions in the EU and their educational capital and economic development rankings (averages).

\begin{tabular}{|c|c|c|c|c|c|c|c|}
\hline 2003 & $\begin{array}{c}\text { Innovative } \\
\text { capacity }\end{array}$ & $\begin{array}{c}\text { Educational } \\
\text { attainment }\end{array}$ & $\begin{array}{c}\text { Economic } \\
\text { development }\end{array}$ & & $\begin{array}{c}\text { Innovative } \\
\text { capacity }\end{array}$ & $\begin{array}{c}\text { Educational } \\
\text { attainment }\end{array}$ & $\begin{array}{c}\text { Economic } \\
\text { development }\end{array}$ \\
\hline Upper Bavaria (GER) & 3,5 & 85 & 8 & West Sweden (SWE) & 11,5 & 40 & 37,5 \\
\hline Stuttgart (GER) & 3,5 & 102 & 17 & Karlsruhe (GER) & 12 & 75 & 24 \\
\hline Darmstadt (GER) & 8 & 65 & 13,5 & South Sweden (SWE) & 12 & 35,5 & 60 \\
\hline Tübingen (GER) & 8,5 & 83 & 33 & Middle Franconia (GER) & 15 & 136 & 28 \\
\hline Capital Reg. Of Denmark (DEN) & 9,5 & 2 & 8 & Île de France (FRA) & 15,5 & 47 & 5 \\
\hline North Brabant (NED) & 11 & 56 & 58,5 & Braunschweig (GER) & 16,5 & 139,5 & 84,5 \\
\hline Stockholm (SWE) & 11,5 & 9 & 6 & South Finland (FIN) & 17 & 12 & 45,5 \\
\hline 2007 & $\begin{array}{c}\text { Innovative } \\
\text { capacity }\end{array}$ & $\begin{array}{c}\text { Educational } \\
\text { attainment }\end{array}$ & $\begin{array}{c}\text { Economic } \\
\text { development }\end{array}$ & & $\begin{array}{c}\text { Innovative } \\
\text { capacity }\end{array}$ & $\begin{array}{c}\text { Educational } \\
\text { attainment }\end{array}$ & $\begin{array}{c}\text { Economic } \\
\text { development }\end{array}$ \\
\hline Stuttgart (GER) & 1,5 & 101 & 21 & North Brabant (NED) & 15 & 51,5 & 44,5 \\
\hline Upper Bavaria (GER) & 3,5 & 73 & 12 & Karlsruhe (GER) & 15,5 & 101 & 32,5 \\
\hline Stockholm (SWE) & 9,5 & 23 & 6 & Middle Franconia (GER) & 17,5 & 129,5 & 36,5 \\
\hline Capital Reg. Of Denmark (DEN) & 10 & 6,5 & 7 & Freiburg (GER) & 21,5 & 104 & 62 \\
\hline Tübingen (GER) & 10 & 106,5 & 37,5 & Île de France (FRA) & 21,5 & 71,5 & 6 \\
\hline Darmstadt (GER) & 11,5 & 88 & 16,5 & West Sweden (SWE) & 22 & 51 & 39 \\
\hline South Sweden (SWE) & 14 & 35 & 54,5 & South Finland (FIN) & 23,5 & 8 & 38,5 \\
\hline
\end{tabular}

